\title{
Penyuluhan Mengenai Pentingnya Physical Distancing, Social Distancing, Serta Program Phbs Untuk Memutus Rantai Penyebaran Covid-19
}

\author{
Sandra Lestari ${ }^{1}$ dan Agung Wibowo ${ }^{2}$, \\ ${ }^{1}$ Universitas Sebelas Maret \\ ${ }^{2}$ Universitas Sebelas Maret \\ agungwibowo@staff.uns.ac.id
}

\begin{abstract}
Abstrak
Coronavirus disease Covid-19 merupakan penyakit infeksius yang menyerang tidak hanya di Indonesia, tetapi di seluruh belahan dunia. Saat ini di Indonesia jumlah angka kasus positif Covid-19 belum mengalami penurunan, tetapi justru semakin meningkat setiap hari. Hal ini membuktikan bahwa kesadaran masyarakat akan bahaya Covid-19 masih rendah. Pemerintah Indonesia sendiri telah melakukan upaya untuk mengurangi jumlah angka kasus positif Covid-19. Pengabdian masyarakat ini difokuskan pada Penyuluhan Mengenai Pentingnya Physical Distancing, Social Distancing, Serta Program Pola Hidup Sehat untuk membantu meningkatkan kesadaran masyarakat di Kelurahan Pusaka Rakyat, Kecamatan Tarumajaya, Bekasi, Jawa Barat. Metode pelaksanaan pengabdiam dilaksanakan berdasarkan tema besar supporting pemahaman masyarakat terhadap COVID-19 dilakukan dengan metode secara daring dan luring. Metode daring dengan kegiatan berupa edukasi online melalui Instagram (@sandrachaaw) dan grup Whatsapp Kompleks berbasis diskusi bersama, dan dilakukan secara luar jaringan (luring) dengan kegiatan berupa edukasi offline dengan mencetak poster (ditempel di taman kompleks), brosur (dibagikan kepada warga), pembagian masker, vitamin C, penyediaan hand sanitizer dan sabun cuci tangan di ruang publik. Hasil pelaksanaan kegiatan adalah adanya peningkatan kesadaran masyarakat mengenai bahaya Covid-19, yang ditunjukkan dalam kehiduoan keseharian dengan tetap mematuhi himbauan dan protokol kesehatan dari pemerintah.
\end{abstract}

Kata Kunci: Covid-19, Penyuluhan, Social Distancing

\section{PENDAHULUAN}

Kuliah Kerja Nyata merupakan salah satu bentuk pendidikan dengan cara memberikan pengalaman belajar kepada mahasiswa untuk hidup ditengah-tengah lingkungan masyarakat di luar kampus, dan mengidentifikasi serta menangani masalah-masalah pembangunan yang dihadapi. KKN dilakukan oleh perguruan tinggi dalam upaya meningkatkan isi dan bobot pendidikan bagi mahasiswa dan untuk mendapatkan nilai tambah yang lebih besar pada pendidikan tinggi (Anasari, Suyatno and Astuti 2015). Keterlibatan perguruan tinggi melalui salah satu tri Dharma Perguruan Tinggi yakni dengan program pengabdian masyarakat yang dilakukan Bersama antara dosen dan mahasiswa. Pada pengabdian ini dilakuakn melaui Kuliah Kerja Nyata tematik integratif yang fokus untuk mengatasi masalah Virus Covid-19.

Pemberdayaan atau pengembangan masyarakat Belum dimuat pada refrensi

merupakan usaha untuk menjadikan masyarakat menjadi subjek pembangunan dalam meningkatkan taraf kesejahteraan hidupnya (Bahua, 2016). Pengembangan masyarakat merupakan proses

$$
\text { Ekonomi, Sosial, dan Budaya }
$$


pembangunan kesadaran kritis yang dilakukan secara transformatif, partisipatif, sistematis dan berkesinambungan melalui pengorganisasian dan peningkatan kemampuan menangani berbagai persoalan dasar yang mereka hadapi untuk mengarah pada perubahan kondisi hidup yang semakin baik sesuai dengan cita -cita yang diharapkan. Jadi yang dimaksud dengan istilah pengembangan masyarakat dalam studi ini adalah proses penyadaran masyarakat yang dilakukan oleh seluruh komponen masyarakat secara bersamasama, dengan tujuan memenuhi kebutuhan serta mencari solusi atas permasalahan yang dihadapi oleh mereka (Cunningham, 2017).

Penyuluhan sebagai proses perubahan terencana yaitu adanya perubahan yang tidak alami atau terencana terutama disebabkan oleh dua alasan pokok. Alasan pertama adalah adanya keinginan manusia untuk memenuhi kebutuhan atau memecahkan dengan memodifikasi sumber daya dan lingkungan hidupnya. Alasan kedua adalah ditemukannya inovasi yang memberikan peluang bagi manusia untuk memenuhi kebutuhan atau memperbaiki kesejahteraan hidupnya.

Apabila tidak terjadi perubahan, maka akan terjadi kemandegan dan kehidupan tidak dapat berkembang seperti yang diharapkan. Perubahan terencana merupakan istilah yang pertama kali diperkenalkan oleh Kurt Lewin untuk membedakan perubahan yang sengaja digerakkan dan direncanakan dengan perubahan yang berlangsung tidak sengaja. Biasanya apabila perubahan yang dilakukan itu secara terencana, penyuluh memiliki visi; baik itu cita-cita, harapan, pandangan, tujuan, dan masa depan (Arijanto, et al., 2018).

Perubahan terencana dilakukan untuk mempersiapkan masyarakat menghadapi perubahan lingkungan yang semakin cepat, dalam kontek ini adalah mempersiapkan kehidupan new normal pasdca pendemi Covid-19. Kegiatan yang pengujian serta mendemonstrasikan merupakan bagian dari perubahan terencana yang sudah dirumuskan. Sebuah inovasi tidak selalu cocok baik dalam hal teknis, ekonomis, sosial-budaya, dan politik/ kebijakan untuk diimplementasikan kepada masyarakat. Langkah uji coba dan demonstrasi sangat penting dilaksanakan. Kegiatan uji coba juga penting agar diperoleh gambaran tentang beragam alternatif yang paling menguntungkan dan pengorbanan yang paling rendah (Maryani dan Nainggolan, 2019).

Suatu perubahan secara terencana dan terprogram secara berkesinambungan dil;akukan agar masyarakat mengetahui dan mempunyai kemauan serta dapat memahami bahkan dapat dapat mengelola sumberdaya. Seorang fasilitator harus memiliki keterampilan dan keahlian untuk memilih alternatif perubahan yang tepat, yang secara teknis dapat dilaksanakan dan secara ekonomis menguntungkan. Seorang fasilitator harus mampu dan berbuat secara melayani, memberi petunjuk dan contoh dalam bentuk peragaan dan mengerjakan sendiri dalam memecahkan suatu masalah yang sedang dihadapi (Damanik, 2020).

Pengembangan kebutuhan untuk melakukan perubahan-perubahan terencana meliputi diagnosa masalah, pemilihan obyek, dan analisis tentang motivasi dan kemampuan masyarakat. Proses diagnosa bukan hanya sekedar mengidentifikasi jenis dan karakteristiknya, serta latar belakang dari suatu kelemahan masalah tertentu melainkan mengimplikasikan suatu upaya untuk meramalkan kemungkinan dan menyarankan tindakan pemecahannya (Fanny, et al., 2017). Fasilitator memiliki pengetahuan dan pengalaman yang di transformasikan ke dalam suatu area. Perlu adanya penyuluhan dari seorang pakar untuk memberikan pemahaman atau informasi kepada orang yang membutuhkan informasi. Diagnosa memiliki tujuan untuk memudahkan penyampaian informasi untuk dapat menanggulangi permasalahan dengan menggunakan sebuah sistem tertentu (Purwanto dan Destiani, 2015).

$\begin{array}{cccc}\text { Model } & \text { sistem } & \text { penyuluh yang } & \text { dapat } \\ \text { mendiagnosa } & \text { dan } & \text { memberikan } & \text { solusi }\end{array}$ penanggulangan sebagai salah satu alat bantu alternatif dalam menghadapi masalah-masalah. Diagnosa dapat mengidentifikasi dengan jelas sehingga dapat memberikan solusi yang tepat dalam mengambil keputusan yang tepat (Yulianto, et al., 2015). Metode untuk mendiagnosis masalah berdasarkan permintaan yang diterima dari lokasi meliputi langkah-langkah menentukan rekomendasi solusi yang berlaku berdasarkan permintaan dan

$$
\text { Ekonomi, Sosial, dan Budaya }
$$

934 
diagnosis. Menampilkan rekomendasi solusi yang berlaku berbasis penalaran terhadap kasus yang tersedia. Metode menyajikan penalaran berbasis kasus di layar dengan rekomendasi solusi yang berlaku (Ruppelt, 2003).

Diagnosasi dikembangkan dengan pengembangan kebutuhan untuk melakukan perubahan-perubahan. Ada beberapa hubungan antara perilaku sistem tingkat rendah dan masalah tinggi dan diagnosis masalah adalah metode pemecahan masalah yang menjanjikan dengan akurasi dan generalisasi yang baik. Diagnosis masalah memperhatikan keakuratan prediksi kesalahan (Yuan, et al., 2006). Keefektifan program dipengaruhi oleh metode yang dipilih dan cara penggunaan metode tersebut (Ban dan Hawkins, 1999). Pemilihan obyek sebaiknya merupakan hasil rekomendasi dari kegiatan potensi penyuluhan (Waskito dan Arnowo, 2017).

Coronavirus disease (Covid-19) adalah suatu penyakit infeksius yang disebabkan oleh corona virus yang baru ditemukan. Sebagian besar orang terinfeksi oleh virus Covid-19 akan mengalami gangguan pada saluran napas yang bersifat ringan sampai sedang dan dapat sembuh sendiri tanpa membutuhkan perawatan khusus. Penyebaran virus Covid-19 terutama melalui droplet dari ludah atau cairan yang keluar dari hidung pada saat orang yang terinfeksi batuk atau bersin, sehingga penting untuk melatih etiket pernapasan (contohnya, dengan batuk ke siku yang ditekuk) (WHO, 2020). Wabah awal dilaporkan di Huanan Seafood Wholesale Market, in Wuhan, Hubei, China pada Desember 2019 dan melibatkan sekitar $66 \%$ staf sana. Pasar ditutup pada 1 Januari 2020, setelahnya pengumuman peringatan epidemiologis oleh otoritas kesehatan setempat pada 31 Desember 2019 (Wu, Chena and Chan 2020). Pada awal penyakit, manifestasi utama Covid-19 adalah kelelahan, demam, batuk kering, nyeri otot, dan sesak napas, dengan lebih sedikit gejala umum adalah hidung tersumbat, sakit kepala, pilek, sakit tenggorokan, muntah dan diare. Pasien yang parah sering memiliki sesak napas dan / atau hipoksemia 1 minggu setelah onset, setelah itu syok septik, ARDS, asidosis metabolik yang sulit diperbaiki, dan disfungsi koagulasi berkembang dengan cepat. Dari catatan, parah dan kritis pasien juga hanya dapat disertai dengan demam rendah, atau bahkan tidak ada demam yang jelas, dan pasien ringan hanya menunjukkan demam rendah, kelelahan ringan dan tidak ada pneumonia. Ini kasus asimptomatik atau ringan juga bisa menyebarkan SARS-CoV-2 pada manusia (Li, et al. 2020).

Bekasi Barat merupakan salah satu kecamatan dengan pasien positif Corona terbanyak di Kota Bekasi berdasarkan Data Sebaran Covid-19 di Kota Bekasi. Dilansir dari liputan6.com, Kecamatan Tarumajaya saat ini didapatkan kasus baru positif Covid-19. Hal ini cukup mengejutkan karena sebelumnya Kecamatan Tarumajaya belum didapatkan adanya kasus positif Covid-19. Oleh karena itu, melalui KKN Covid-19 relawan berharap dapat memberikan penyuluhan mengenai pentingnya physical distancing, social distancing, dan PHBS sebagai bentuk upaya meningkatkan pemahaman, kesadaran, dan kewaspadaan masyarakat untuk memutuskan rantai penyebaran Covid-19.

\section{METODE}

Kegiatan ini dilaksanakan di Kompleks Taman Puspa RT 003 RW 005, Kelurahan Pusaka Rakyat, Kecamatan Tarumajaya, Bekasi Jawa Barat, Pemilihan lokasi didaarkan atas pertimbangan bahwa penlis berada di wilayah kompleks tersebut sehingga penulis memahami kebutuhan dan karakter social budaya masyarakat setempat. Di saming itu juga untuk untuk meminimalisir kendalakendala yang akan dilakukan.

Program kerja dilaksanakan berdasarkan tema besar supporting pemahaman masyarakat terhadap COVID-19. Tema supporting pemahaman masyarakat terhadap COVID-19 dilaksanakan dengan metode secara daring dan metode luring. Metode secara daring dilakukan dengan kegiatan berupa edukasi online melalui Instagram (@sandrachaaw) dan edukasi online melalui grup Whatsapp Kompleks Taman Puspa berbasis diskusi bersama. Mentode sercara luar jaringan (luring) dengan kegiatan berupa edukasi offline dengan mencetak poster (ditempel di taman kompleks) dan brosur (dibagikan kepada setiap warga yang masuk ke kompleks).

Kegiatan ini dilakukan selama 45 hari di lokasi. Pada saat kegiatan luring, penulis Ekonomi, Sosial, dan Budaya 935 
menggunakan protocol kesehatan lengkap dan koordinasi dengan tokoh masyarakat dan pengurus RW dan RT setempat.

\section{HASIL DAN PEMBAHASAN}

\section{Edukasi daring via Instagram}

Program ini bertujuan untuk memberikan informasi kepada orang- orang mengenai informasi seputar Covid-19. Informasi yang dibagi antara lain adalah Social Distancing/ Physical Distancing, cara menerapkan PHBS selama pandemi Covid-19, Penyebaran Covid-19, 7 langkah mencuci tangan, dan perbedaan OPD, PDP, OTG, dan kontak erat. Informasi yang dibagi sebanyak 1 post dalam sehari.
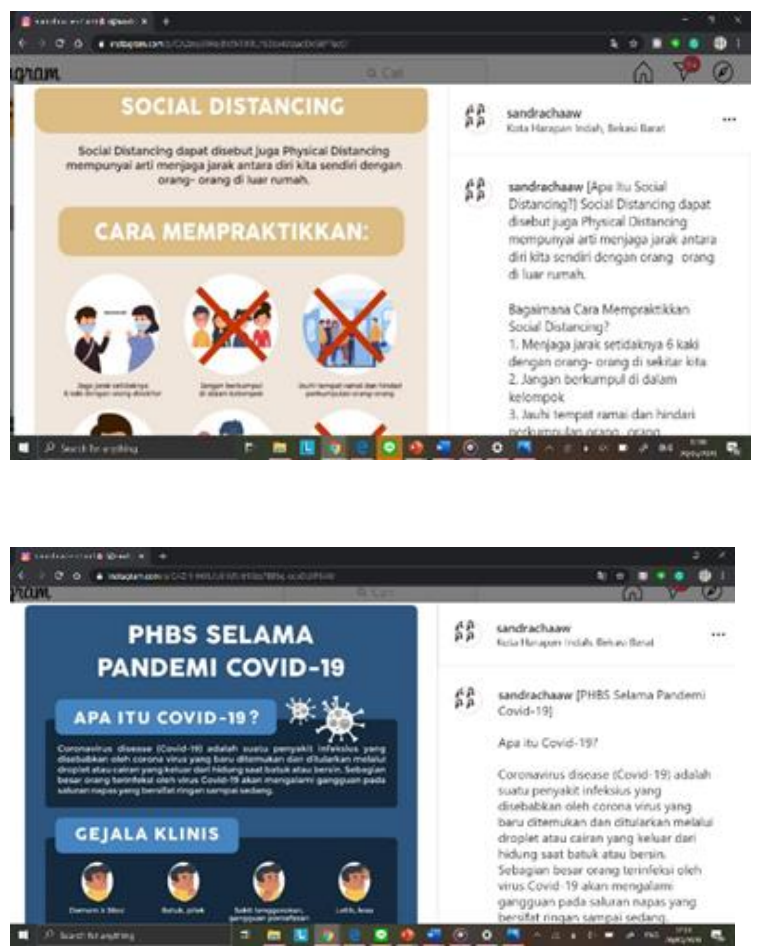
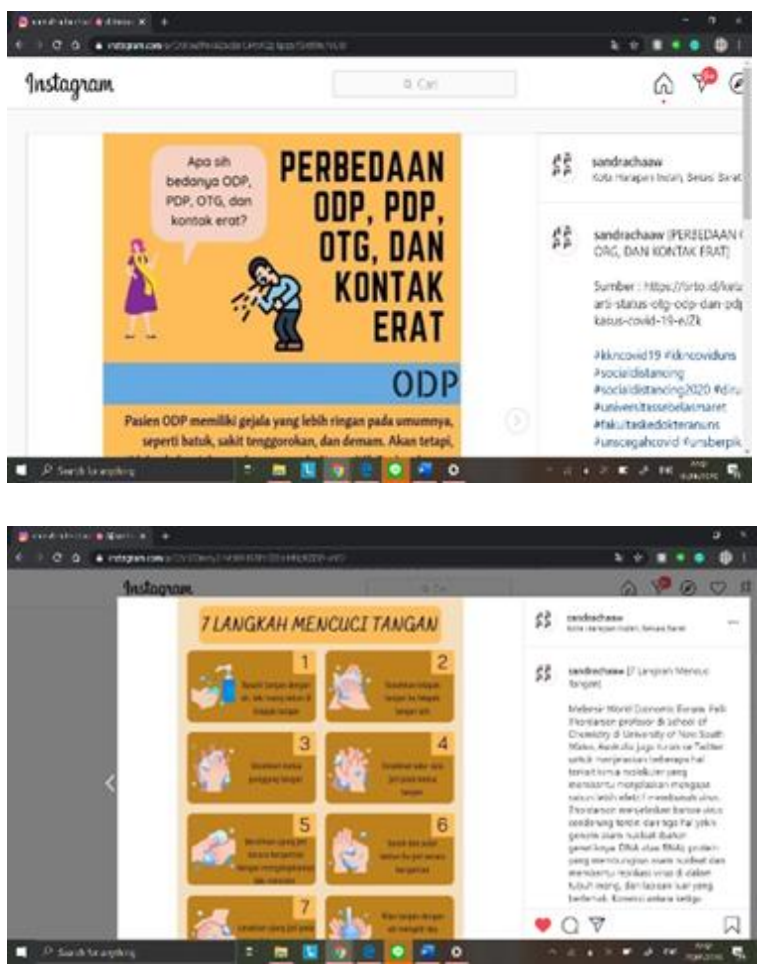

Gambar 1. Edukasi daring via Instagram

\section{Edukasi daring via grup Whatsapp}


Program ini bertujuan untuk memberikan informasi kepada orang- orang di Kompleks Taman Puspa RT 03 RW 015, Kelurahan Pusaka Rakyat, Kecamatan Tarumajaya, Bekasi, Jawa Barat yang berjumlah 36 kepala keluarga. Informasi yang dibagi antara lain adalah Social Distancing/ Physical Distancing, cara menerapkan PHBS selama pandemi Covid-19, Penyebaran Covid-19, 7 langkah mencuci tangan, dan perbedaan OPD, PDP, OTG, dan kontak erat. Warga Kompleks Taman Puspa juga dapat melakukan sesi bertanya jika terdapat hal yang tidak dimengerti atau bertanya mengenai informasi di luar topik yang disampai di grup seperti vaksin untuk Covid-19 dan cara meningkatkan imunitas untuk mencegah penularan Covid-19.

Beberapa aktivitas diskusi baik melalui instragram mauun grup WA disambu antusisa oleh warga masyarakat, karena earga masyarakat sangat memerlukan informasi seputir Covid-19.
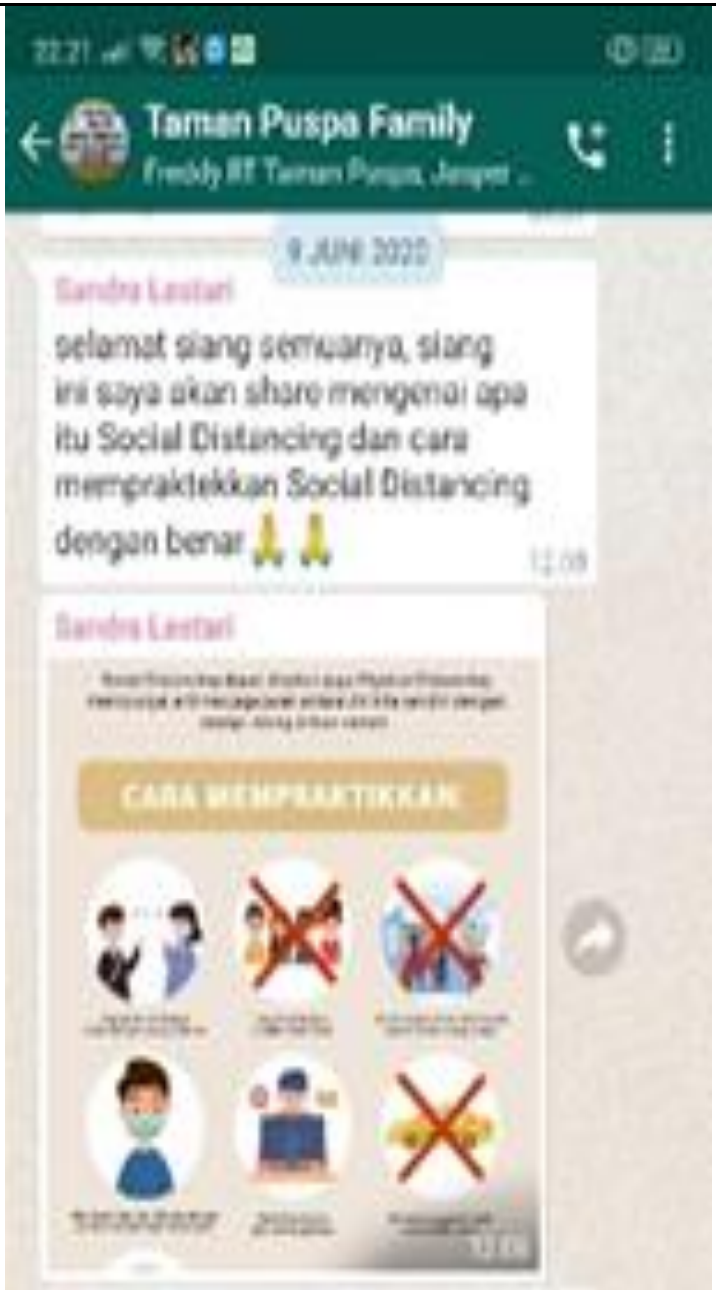

Alingatianiat)

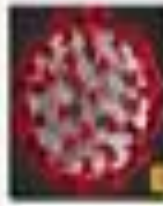

Corceavira Diasse 2016 (COVID-19)

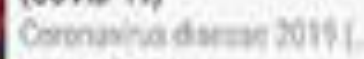
waw adcos

[Apa litu Social Distaneing? Social Distancing capst distobs jus

(6) Irik pesan 

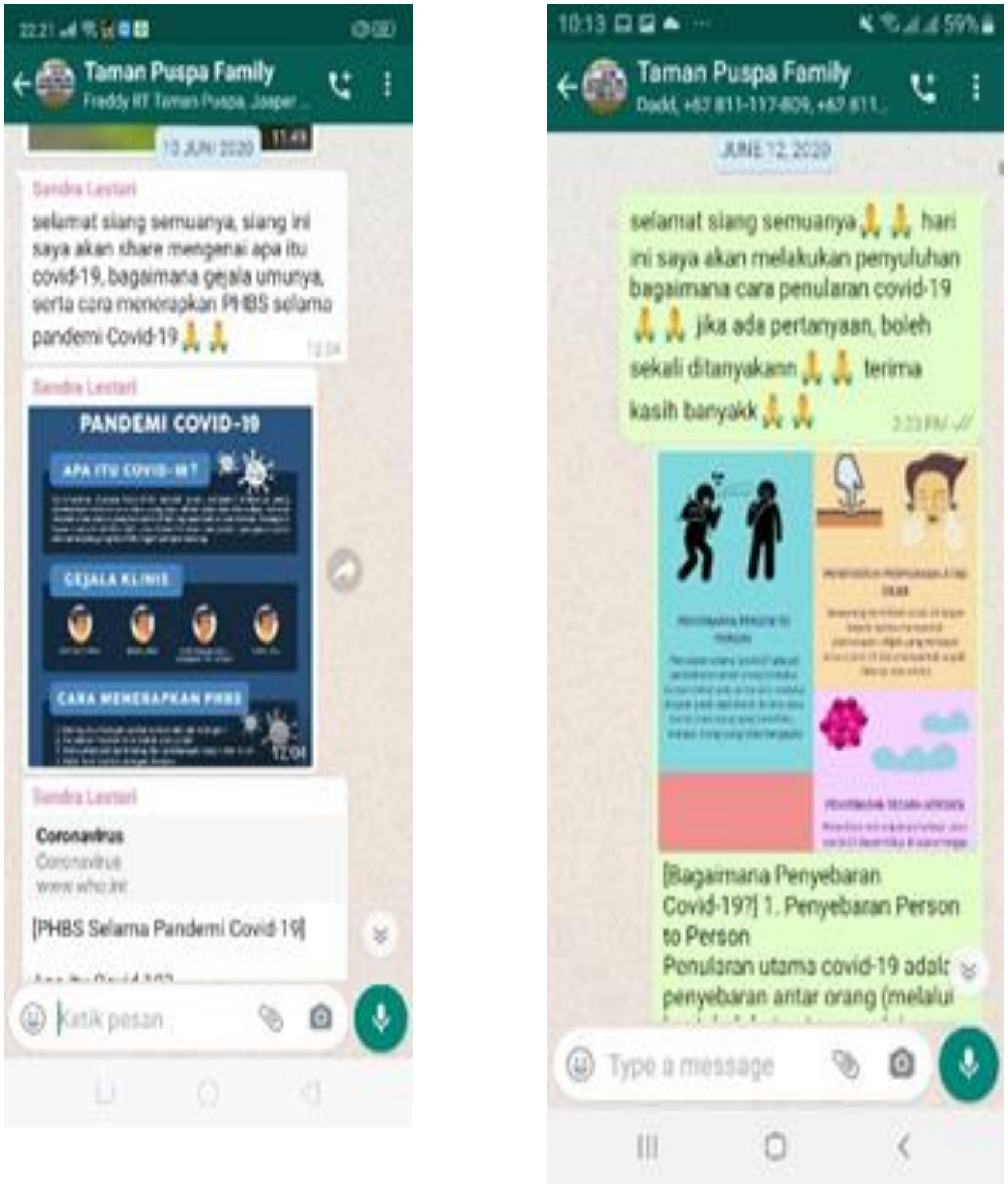

Ekonomi, Sosial, dan Budaya 


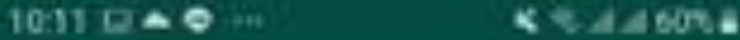 \\ \& F. Taman Puspa Family

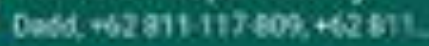

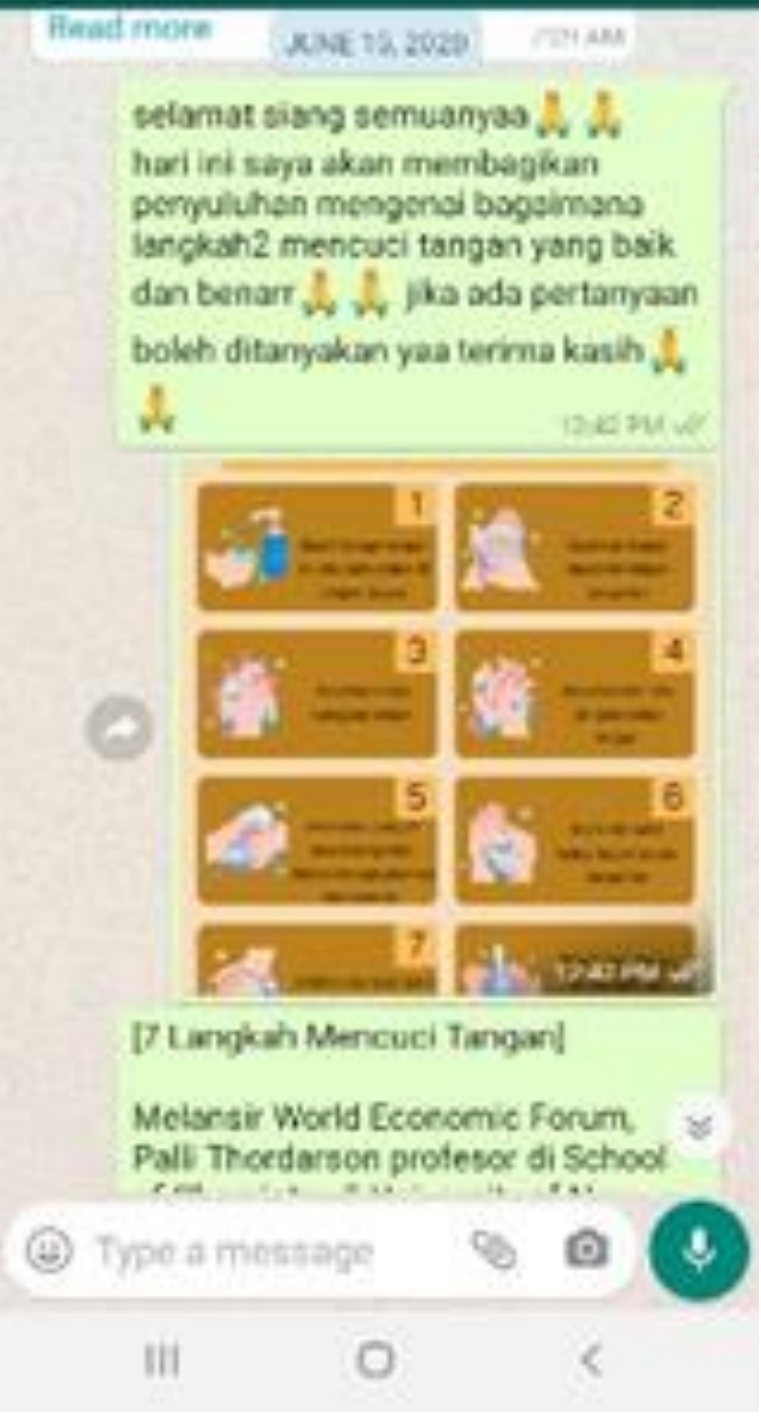

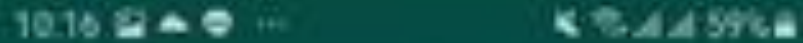

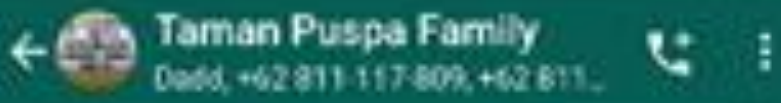

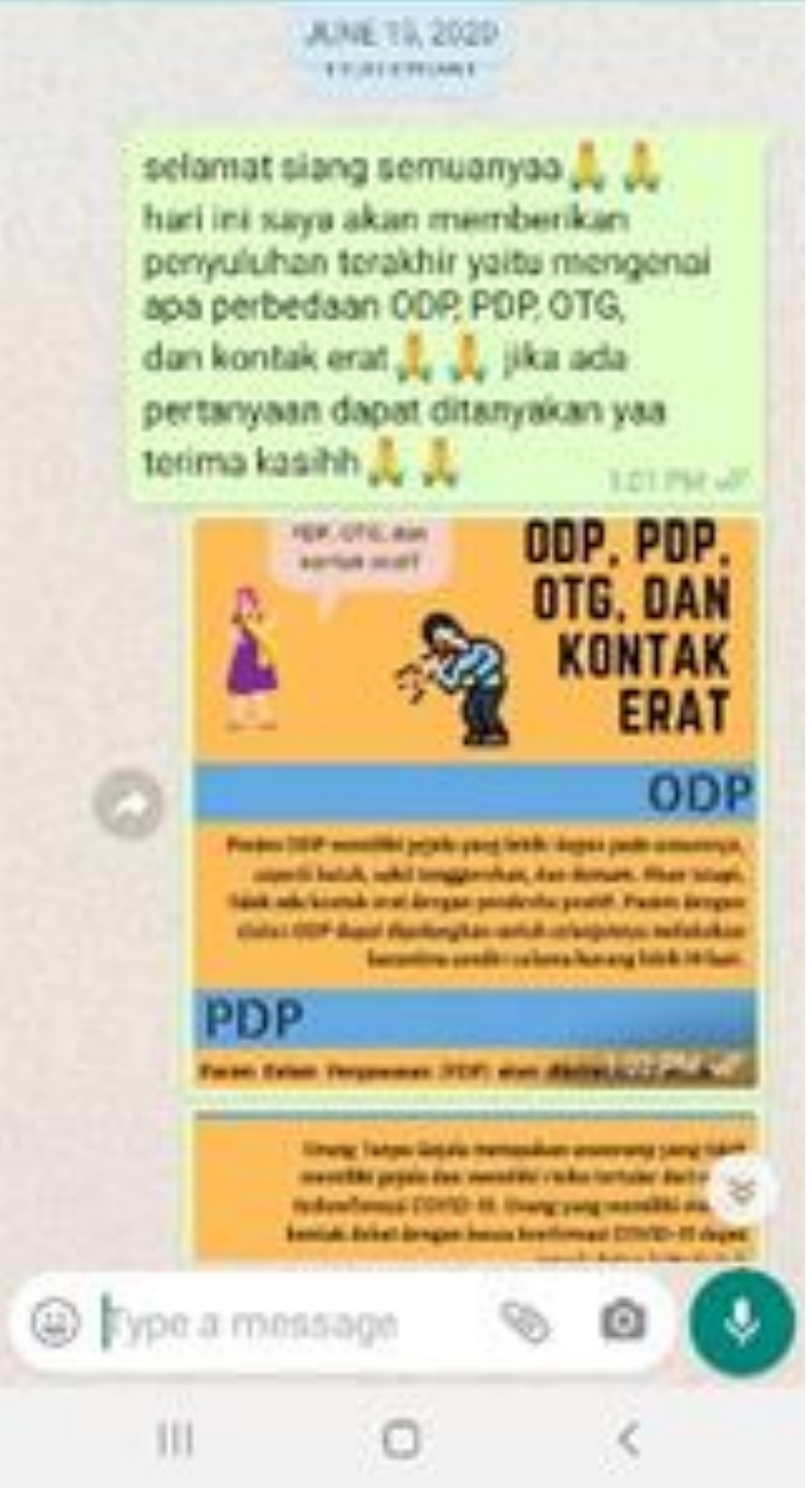

Gambar 2.

Edukasi daring via Whatsapp 


\section{Pembagian masker, hand sanitizer, vitamin C, dan sabun cuci tangan}

Kegiatan ini dilakukan hanya sekali selama satu periode KKN. Penulis membagikan masker, hand sanitizer, vitamin $\mathrm{C}$, dan sabun cuci tangan kepada satpam dan tukang kebun kompleks. Relawan membagikan barang- barang tersebut karena satpam dan tukang kebun kompleks menjadi garda terdepan dalam melindungi warga- warga kompleks Taman Puspa dan mereka sering terpapar dengan udara luar. Oleh karena itu relawan membagikan barang- barang tersebut sebagai bentuk upaya meningkatkan imunitas serta membantu mencegah paparan virus Covid-19 pada satpam dan tukang kebun kompleks. Relawan juga memberikan edukasi kepada satpam dan tukang kebun kompleks mengenai informasi seputar Covid19.

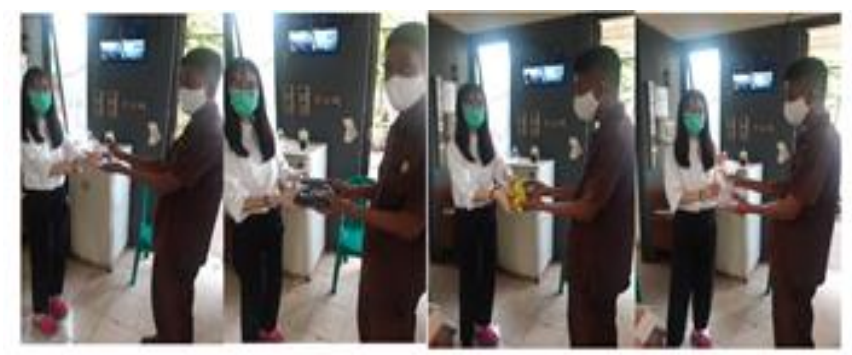

Gambar 3.

Membagikan masker, hand sanitizer, vitamin $\mathrm{C}$, dan sabun

Pembagian brosur Social Distancing dan PHBS, membagikan stiker kepada setiap warga yang masuk ke kompleks, dan memasang poster Social Distancing dan PHBS di taman kompleks

Kegiatan ini dilakukan hanya sekali selama satu periode KKN. Penulis membagikan brosur serta stiker kepada setiap warga yang masuk ke kompleks. Penulis dibantu oleh satpam kompleks untuk membagikan brosur dan stiker. Relawan juga memasang poster di taman kompleks dan dibantu oleh satpam kompleks.
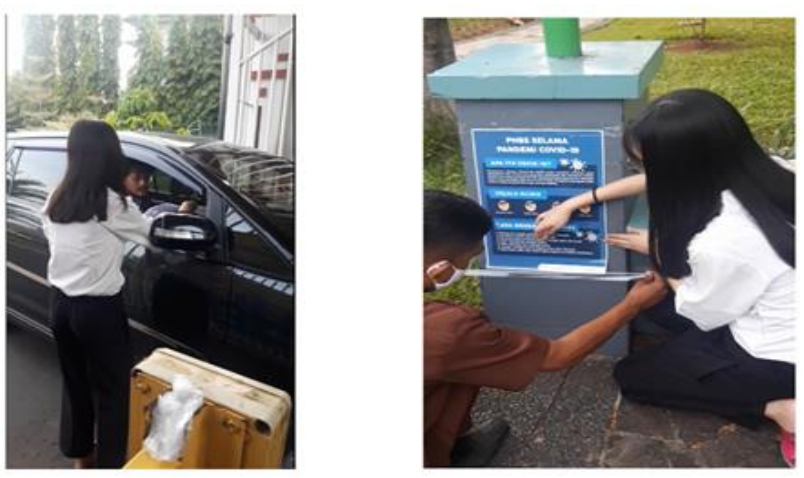

Gambar 4.

Pembaagiann brosur kepada warga yang masuk ke kompleks dan memasang poster di taman kompleks

Evaluasi Program

Program KKN yang dilakukan di Kompleks Taman Puspa RT 003 RW 015, Kelurahan Pusaka Rakyat, Kecamatan Tarumajaya, Bekasi, Jawa Barat belum sepenuhnya memberi dampak yang signifikan karena KKN ini dilaksanakan selama 45 hari dan hanya satu mahasiswa yang terlibat untuk mempertanggung jawabkan kegiatan ini. Program yang dilaksanakan sudah efektif dalam memberikan informasi kepada warga kompleks serta satpam dan tukang kebun kompleks dan mereka dapat menerima informasi dengan baik, meskipun dalam beberapa hal belum sepenuhnya efisien.

Selama dilaksanakan program KKN ini, warga kompleks Taman Puspa menjadi lebih waspada dan sadar akan bahaya Covid-19 setelah membaca brosur dan poster yang dibagikan relawan. Bahkan setelah dibagi masker, hand sanitizer, vitamin c, dan sabun cuci tangan, satpam dan tukang kebun kompleks menjadi lebih semangat untuk bekerja dan melindungi warga kompleks Taman Puspa.

Ekonomi, Sosial, dan Budaya 


\section{KESIMPULAN}

KKN UNS Era Covid-19 merupakan bentuk kepedulian serta pengabdian kepada masyarakat selama pandemi Covid-19 yang diselenggarakan oleh Universitas Sebelas Maret Surakarta (UNS) dan dilaksanakan oleh seluruh mahasiswa UNS. Mahasiswa UNS melaksanakan program KKN selama pandemi Covid-19 di daerah masingmasing, salah satunya di Kompleks Taman Puspa RT 003 RW 015, Kelurahan Pusaka Rakyat, Kecamatan Tarumajaya, Bekasi, Jawa Barat. Tema besar yang diambil adalah supporting pemahaman masyarakat terhadap Covid-19. Program KKN yang dilaksanakan selama 45 hari, yakni mulai tanggal 25 Juni /d 10 Agustus 2020 ini telah memberikan banyak dampak positif kepada masyarakat RT 003 RW 015, Kelurahan Pusaka Rakyat, Kecamatan Tarumajaya, Bekasi, Jawa Barat antara lain adalah meningkatnya pemahaman masyarakat mengenai bahaya Covid-19 serta mengetahui bagaimana cara mencegah penyebaran virus Covid-19. Evaluasi dilaksanakan dengan memberikan pertanyaan singkat yang dihare via wa grup.

\section{UCAPAN TERIMAKASIH}

Ucapan terimakasih disampaikan kepada Lembaga Penelitian dan Pengabdian Masyarakat Universitas Sebelas maret yang telah memberikan kontribusi dalam pelaksanaan kegiatan melalui Skim Kuliah Kerja Nyata.

\section{REFERENSI}

Anasari, Fitri, Addy Suyatno, and Indah Fitri Astuti. (2015). "Lembaga Pengabdian kepada Masyarakat Universitas Mulawarman)." Jurnal Informatika Mulawarman 10 (1): 12.

Arijanto, A., Perkasa, H. D., Widayati, C. C., Wuryandari, R. E. N. (2018). Manajemen Perubahan. Jakarta: Halaman Moeka Publishing.

Asosiasi Pengguna Jasa Internet Indonesia (2016). Penetrasi dan Perilaku Pengguna Internet Indonesia, Survey 2016.
Bahua, M. I. (2016). Assessing Professional Competencies of Agricultural Extension Workers: A Case Study of Indonesian's Agribusiness Sector. International Journal of Agriculture Innovations and Research, 4(4), 743-746.

Ban, D. V. W. A., dan Hawkins, S. H. 1999. Penyuluhan Pertanian. Yogyakarta: Kanisius.

Cunningham, Gord, Alison Mathie. (2017). Who is Driving Development? Reflections on the Transformative Potential of Asset-based Community Development. J. of Development Studies, 1(26): 175- 186.

Damanik, E. S. (2020). Buku Ajar Sosiologi Kehutanan. Ponorogo: Uwais Insprirasi Indonesia.

Fanny, R. R., Hasibuan, A. N., Buulolo, E. (2017). Perancangan Sistem Pakar Diagnosa Penyakit Asidosis Tubulus Renalis Menggunakan Metode Certainty Factor dengan Penelusuran Forward Chaining. Jurnal Media Informatika Budidarma. Vol 1(1): 13-16.

Li, Heng, Shang-Ming Liu, Xiao-Hua Yu, Shi-Lin Tang, and Chao-Ke Tang. (2020). "Coronavirus disease 2019 (COVID-19): current status and future perspectives." International Journal of Antimicrobial Agents 3.

Maryani, D., dan Nainggolan E. R. R. (2019). Pemberdayaan Masyarakat. Yogyakarta: Deepublish.

Nayani ZS, Hendre PC. (2015). Comparision and Correlation of Pap Smear with Colposcopy and Histopathiology in Evaluation of Cervix. Journal of Evolution of Medical and Dental Sciences, 4(53): 9236 - 9247.

Ekonomi, Sosial, dan Budaya 941 
Purwanto, T., dan Destiani, D. (2015). Pengembangan Sistem Pakar Diagnosis Penyakit Cabai. Jurnal Algoritma. Vol 12(2): 510-516.

Ruppelt Michael Kevin. (2003). Method and Apparatus for Problem Diagnosis and Solution. United States Patent. Vol 17(30): 18.

Sinulingga, Bam. (2020). Nihil Kasus Positif, 5 Kecamatan di Kabupaten Bekasi Kembali

Terpapar Corona. Diambil dari: https://www.liputan6.com/news/read/427712 3/nihil kasus-positif-5-kecamatan di kabupaten-bekasi-kembali-terpapar-corona WHO. 2020. Coronavirus. Accessed June 28, $2020 . \quad$ https://www.who.int/healthtopics/coronavirus\#tab=tab_1.

Wu, Yi-Chi, Ching-Sung Chena, and Yu-Jiun Chan. (2020). "The outbreak of COVID-19: An overview." J Chin Med Assoc 217.Huang, X., \& Xie, Y. M. (2010). Evolutionary Topology Optimization of Contimuum Structures: Methods and Applications. Chichester: John Wiley and Sons, Ltd. Publication.

Waskito dan Arnowo, H. (2017). Pertanahan, Agraria, dan Tata Ruang. Jakarta: Kencana.

Yuan Chun, et al. 2006. Automated Known Problem Diagnosis with Event Traces. Associating for Computing Machinery SIGOPS Operating Systems Review. Vol 40(4): 376-388.

Yulianto, et al. 2015. Model Sistem Pakar Diagnosa Hama Tanaman Padi untuk Memberikan Solusi Penanggulangan. Jurnal Semnastoknomedia Online. Vol 3(1): 7-12. 